\title{
LEAD CONTAMINATION AND BIOACCUMULATION IN A LOTIC ECOSYSTEM AROUND AN ABANDONED MINING AREA OF KHLI TI CREEK, KANCHANABURI PROVINCE, THAILAND
}

\author{
ZungBudda, P. $^{1}-$ BoOnsoong, B. ${ }^{2}-$ ChAichanA, R..$^{*}$ \\ ${ }^{I}$ Department of Environmental Technology and Management, Faculty of Environment \\ Bangkok, Thailand \\ ${ }^{2}$ Department of Zoology, Faculty of Science, Kasetsart University, Bangkok, Thailand \\ *Corresponding author \\ e-mail: fscircc@ku.ac.th; phone: +662-579-2945; fax:+662-579-2946
}

(Received $16^{\text {th }}$ Apr 2018; accepted $26^{\text {th }}$ Feb 2019)

\begin{abstract}
This research investigated the lead contents of the water, sediment and freshwater organisms around an abandoned mining area in Kanchanaburi province, western Thailand. Samples were collected in 2017 during the monsoon season from three zones (upstream or control, middle-stream or inferred source and downstream or impacted zone) of Khli Ti creek. We found that the lead concentration of the water was the highest $(0.0549 \mathrm{mg} / \mathrm{l})$ on average in the downstream zone, and slightly exceeded the national standard level. In the sediment, the lead content was the highest $(31,937.30 \mathrm{mg} / \mathrm{kg})$ in the middle-stream zone and was approximately 25 times higher than the national standard level. The means of other selected heavy metal concentrations in the sediment were the following in descending order: $\mathrm{Fe}>\mathrm{Zn}>\mathrm{As}>\mathrm{Cd}>\mathrm{Hg}$. The results also revealed lead accumulation in freshwater flora and fauna (plankton, macroinvertebrates, fish and macrophytes). Macroinvertebrates, in the middle-stream zone in particular, had the highest lead contents. Our study also showed the potential biomagnification of lead through the food chain. High contents of lead in organisms may cause both acute and chronic effects on stream dwellers on which further detailed research is needed. Lastly, the consumption of freshwater organisms by the local community should be avoided to reduce any health risks.
\end{abstract}

Keywords: environment, heavy metals, invertebrate, stream, water quality

\section{Introduction}

Mining is important for the development of the country since minerals and metal ores such as lead, coal and potash can be used as valuable raw materials for various industries. However, mining operations such as mineral dressing and smelting processes can be a major cause of heavy metal contamination in freshwater bodies because heavy metals are non-biodegradable and can persist in the environment for a very long time (Horowitz et al., 1993; Mazej et al., 2010; Thorslund et al., 2012).

Long term accumulation of heavy metals such as lead, copper and cadmium can reach elevated toxic levels even after the mine has closed, thus creating negative environmental problems (Dudka and Adriano, 1995). Several studies have shown that the water and sediment in lakes and rivers are contaminated by heavy metals. For example, in India, downstream sites in the Yamuna River had high concentrations of cadmium, chromium, iron, nickel and these values exceeded the standard maximum permissible limits prescribed for drinking water (Kaushik et al., 2009). In the Tigris River, Turkey, contamination of arsenic, cadmium, chromium, copper, manganese, nickel and zinc derived from anthropogenic sources was found in sediments (Varol, 2011). In Thailand, manganese (40-382 $\mu \mathrm{g} / \mathrm{l})$ and arsenic $(0.68-8.79 \mu \mathrm{g} / \mathrm{l})$ concentrations in Phayao Lake, northern Thailand, were close to the maxima for 
minimum drinking water standards proposed by USEPA and WHO (Tupwongse et al., 2007).

Heavy metal contamination can also impact biotic components through bioaccumulation and biomagnification (Miller et al., 1992; Goodyear and McNeill, 1999; Mazej et al., 2010). Producers, consumers and predators can be contaminated by heavy metals (Nagayama et al., 2010) through 1) consumption of food and water and 2) from direct exposure via gills and tissue surfaces (Newman and McIntosh, 1991; Goodyear and McNeill, 1999; Lee et al., 2012). The study of Moiseenko and Kudryavtseva (2001) revealed that fish in Russian lakes were contaminated with high concentrations of nickel and copper and showed kidney pathologies. In Thailand, several species of fish (Rasbora tornieri and Systomus rubripinnis) and frog (Kaloula pulvhra and Microhyla heymonsi) have taken up metals such as copper and manganese from the environment around a gold mine area in Loei province (Intamat et al., 2016). Furthermore, heavy metals can biomagnify in aquatic food webs when the heavy metal concentration increases through the trophic levels (Chen et al., 2000; Barwick and Maher, 2003). For example, in the newly-formed wetlands of the Yellow River Delta of China, heavy metals such as cadmium and zinc increased with the trophic level (Cui et al., 2011).

In Thailand, it is known that Kanchanaburi province is a major important source of lead. Lead mining operations in Khli Ti village started in the mid 1960s and then in 1998 the mining was ordered to close due to leakages of toxicants from tailing ponds to Khli Ti creek and surrounding environment (Department of Pollution Control, 2009; Greenpeace Thailand, 2012). Lead and other associate heavy metals from mining are toxic and could cause adverse impacts to the environment and human health if present in large quantities. Therefore, the objectives of this study were to assess the present state of spatial distribution of lead contents in the water and sediment environment of Khli Ti creek and to determine any lead contamination in terms of bioaccumulation and biomagnification in freshwater flora and fauna. The results will be useful to understand lead accumulation in the environment and freshwater organisms and to evaluate potential lead transfer pathways from producers to consumers in a lotic food web.

\section{Materials and methods}

\section{Study site}

Khli Ti creek is located in Chalae sub-district, Thong Pha Phum district, Kanchanaburi province, western Thailand. Its total length is $22 \mathrm{~km}$ and the water flows from north to south ending in the Srinakharind Dam. Sampling locations were divided into three zones: 1) sampling point I in the upstream zone or reference site (14.962309, 98.909397); 2) sampling point II in the middle-stream zone or source of contamination in an old abandoned lead mining area $(14.955716,98.921583)$; and 3) sampling point III in the downstream zone or impacted site $(14.878604,98.948969)$ (Figs. 1, 2). There were five sub-sampling points in each zone and therefore in total there were 15 sub-sampling points along the creek. Data were collected only one time in the rainy season of 2017 due to high water level and suitable time for sampling. 


$$
\text { - } 3899 \text { - }
$$
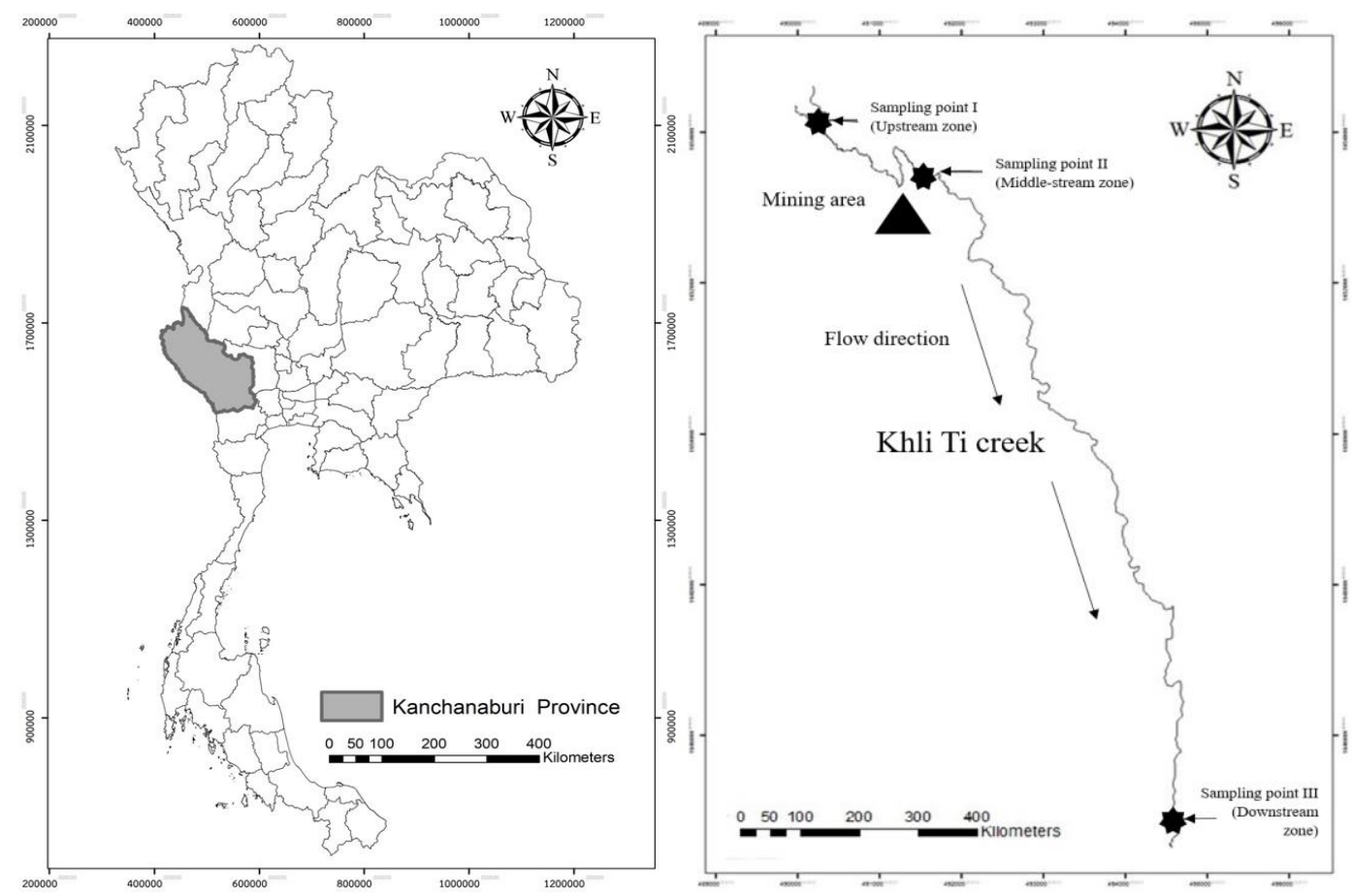

Figure 1. Map of Khli Ti creek (left) and sampling locations in up, middle- and downstream zones (right)

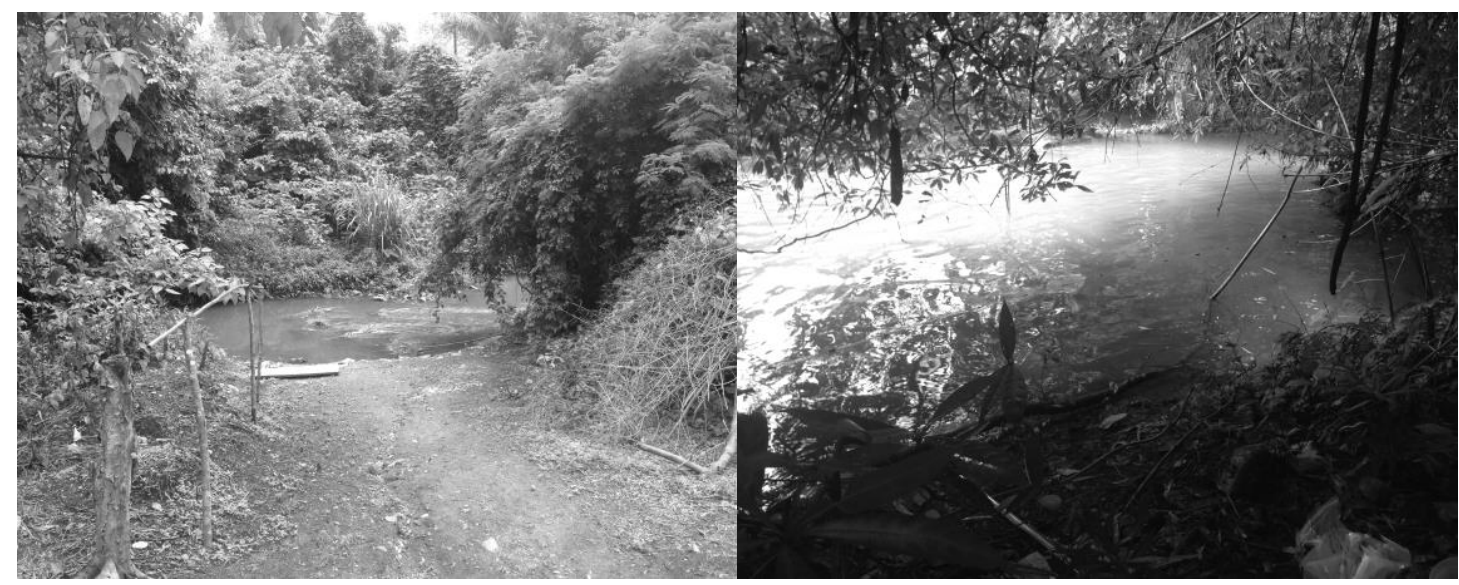

Figure 2. Sampling points around old mining area

\section{Water and sediment sampling}

At each sampling point, we used a multi-parameter analyzer (Consort 663) to measure the water temperature, $\mathrm{pH}$, dissolved oxygen $(\mathrm{mg} / \mathrm{l})$, total dissolved solid $(\mathrm{mg} / \mathrm{l})$ and conductivity $(\mu \mathrm{s} / \mathrm{cm})$. Transparency was measured using a Secchi disk and $2 \mathrm{~L}$ of water were also collected in plastic bottles from each point and then nitric acid was added as preservative and the samples were kept in a cool container for further analysis of total nitrogen $(\mathrm{mg} / \mathrm{l})$ and total phosphorus $(\mathrm{mg} / \mathrm{l})$ at the Department of Soil Science, Kasetsart University, Bangkok, Thailand. Another $1 \mathrm{~L}$ water sample was taken and preserved with nitric acid for lead (mg/l) analysis at the Central Laboratory, 
Bangkok using an in-house method TE-CH-126 based on standard methods for the examination of water and wastewater (APHA, AWWA, WEF $21^{\text {st }}$ edition 2012 Part 3030E) (APHA, 2005) and AOAC (2016) using an inductively coupled plasma mass spectrometer (ICP-MS). Contents of chlorophyll a $(\mathrm{mg} / \mathrm{l})$ were determined using acetone attraction at the Department of Environmental Technology and Management, Faculty of Environment, Kasetsart University, Bangkok, Thailand. All analyses were done in triplicate.

Sediment sampling was conducted at the same water sampling points. Approx. $1 \mathrm{~kg}$ of sediment was collected and transferred to a plastic bag. Sediment samples were air dried, ground into fine powder and sieved through a $0.2-\mathrm{mm}$ sieve. Prepared sediment samples were then analyzed for $\mathrm{pH}$, electrical conductivity (EC, $\mu \mathrm{s} / \mathrm{cm})$ using an electrical conductivity meter, organic matter content (\%) using Walkley and Black titration (Walkley and Black, 1934) and soil texture using the pipette method at the Department of Environmental Technology and Management. Sediment samples (20 g from each sampling point) were also sent to the Central Laboratory for analysis of heavy metals (lead $(\mathrm{Pb})$, iron (Fe), arsenic (As), mercury $(\mathrm{Hg})$, and zinc $(\mathrm{Zn})$ ) using inhouse method TE-CH-329 based on the Environmental Protection Agency (EPA) 3052 standard.

\section{Biotic sampling}

We collected biotic samples and measured their lead contents. Plankton (both phytoplankton and zooplankton) were collected by pouring $50 \mathrm{~L}$ of water through a plankton net with a mesh size of $20 \mu \mathrm{m}$ and $67 \mu \mathrm{m}$. Subsequently, the water was filtered again through Whatman GF/C and kept in a cool plastic container. Benthic macroinvertebrates (mainly shrimp, mollusc, dragonfly nymph and crab) were taken from the sediment using an Ekman grab and invertebrates associated with plants were collected using a hand net (1 min per sampling). Plant and other materials collected from sampling were separated and removed by hand and animals were sorted and kept in plastic bags in an ice box. Fish specimens were collected using gill nets left overnight in the creek and the following day fish samples were retrieved. Samples of fish were kept in an ice container. Freshwater plants present in the creek (mainly taro) were sampled from a $1 \times 1 \mathrm{~m}$ quadrat and whole plant specimens were collected in plastic bags. Plants were identified to the Family level by the Forest Herbarium, Bangkok, Thailand. All biotic samples were sent to the Central Laboratory for analysis of lead contents using in-house method TE-CH-134 based on AOAC (2016) 999.10 and the ICP-MS. Then bioaccumulation factors (BAF) were calculated based on (USEPA, 2001) by using the lead content in aquatic animals $(\mathrm{mg} / \mathrm{kg})$ divided by the lead concentration in water $(\mathrm{mg} / \mathrm{l})$. In addition, biotransference factors (BTF) or biomagnification factors were obtained from the calculation of the lead content in selected consumers or predators divided by that of the selected producer or prey (mg/kg) according to Laskowski (1991).

\section{Data analysis}

Values were reported as mean \pm standard deviation $(n=5)$ throughout. Data distribution was tested by using Test of Homogeneity of Variance and Robust Tests of Equality of Mean (Welch) and then Post Hoc Multiple Comparison (Turkey) was applied to analyze which parameters or variables have different statistical significance among the upstream, middle-stream and downstream zones. 


$$
\text { - } 3901 \text { - }
$$

\section{Results}

\section{Water and sediment properties}

The results of water quality analysis are shown in Table 1. The water temperature was rather low. Transparency was in the range 0.27-0.66 $\mathrm{m}$ and corresponded well with the total suspended solids. The $\mathrm{pH}$ values were neutral and tended to be higher in the downstream zone. The dissolved oxygen contents were relatively high from the upstream to downstream zones. The total nitrogen concentration was high in the upstream zone and gradually decreased toward the downstream zone whereas the total phosphorus concentration was comparable among zones. Significant differences in water quality parameters (temperature, transparency, $\mathrm{pH}$, conductivity, TDS and TSS) were found among zones.

Table 1. Water quality analysis in Khli Ti creek $(n=5)$

\begin{tabular}{|c|c|c|c|}
\hline Parameter & Upstream zone & Middle-stream zone & Downstream zone \\
\hline Temperature (C) & $25.9 \pm 0.6^{\mathrm{a}}$ & $24.9 \pm 0.7^{\mathrm{b}}$ & $26.3 \pm 0.4^{\mathrm{a}}$ \\
\hline Transparency (m) & $0.5 \pm 0.2^{\mathrm{a}}$ & $0.7 \pm 0.3^{\mathrm{a}}$ & $0.3 \pm 0.1^{\text {ab }}$ \\
\hline $\mathrm{pH}$ & $7.96 \pm 0.03^{\mathrm{a}}$ & $8.04 \pm 0.06^{\mathrm{b}}$ & $8.15 \pm 0.05^{\mathrm{c}}$ \\
\hline Conductivity $(\mu \mathrm{s} / \mathrm{cm})$ & $378.2 \pm 10.8^{\mathrm{a}}$ & $409.0 \pm 9.7^{b}$ & $428.8 \pm 3.3^{\mathrm{c}}$ \\
\hline Dissolved oxygen (mg/l) & $12.28 \pm 0.65^{\mathrm{a}}$ & $12.72 \pm 0.62^{\mathrm{a}}$ & $12.32 \pm 0.38^{\mathrm{a}}$ \\
\hline Total dissolved solid (mg/l) & $204.2 \pm 8.7^{\mathrm{a}}$ & $220.0 \pm 3.5^{\mathrm{b}}$ & $230.4 \pm 2.1^{c}$ \\
\hline Total suspended solid (mg/l) & $0.71 \pm 0.35^{\mathrm{a}}$ & $0.89 \pm 0.34^{\mathrm{a}}$ & $4.04 \pm 0.38^{\mathrm{b}}$ \\
\hline Total nitrogen $(\mathrm{mg} / \mathrm{l})$ & $21.00 \pm 14.64^{\mathrm{a}}$ & $14.00 \pm 11.74^{\mathrm{a}}$ & $5.25 \pm 4.79^{\mathrm{a}}$ \\
\hline Total phosphorus (mg/l) & $1.51 \pm 0.90^{\mathrm{a}}$ & $1.57 \pm 0.77^{\mathrm{a}}$ & $2.31 \pm 1.52^{\mathrm{a}}$ \\
\hline Chlorophyll a (mg/l) & $0.51 \pm 0.46^{\mathrm{a}}$ & $0.40 \pm 0.06^{\mathrm{a}}$ & $0.33 \pm 0.0^{\mathrm{a}}$ \\
\hline
\end{tabular}

Mean values followed by different superscript letters are significantly different $(\mathrm{p}<0.05)$

Analysis of the sediment properties revealed that the $\mathrm{pH}$ values were neutral (6.9-7.2) (Table 2). Electrical conductivity was highest in the middle-stream zone and significantly different from that in the upstream and downstream zones. The organic contents of the upstream and middle-stream zones were significantly higher than in the downstream zone. The results of the sediment texture analysis disclosed that the bottom sediment was sandy loam. In particular, the sediment texture of the downstream zone had a lower percentage of sand and a higher percentage of clay and silt compared with the upstream and middle-stream zones.

Table 2. Sediment quality analysis in Khli Ti creek $(n=5)$

\begin{tabular}{|c|c|c|c|}
\hline Parameter & Upstream zone & Middle-stream zone & Downstream zone \\
\hline $\mathrm{pH}$ & $603+025^{a}$ & $710+022^{a}$ & $700+014^{a}$ \\
\hline $\mathrm{EC}(\mu \mathrm{s} / \mathrm{cm})$ & $37003+17225$ & $51080+10205$ & $25032+5555^{a}$ \\
\hline Organic content (\%) & $\begin{array}{r}370.03 \pm 1 / 2.25 \\
{ }^{a} \\
76.59+8.46\end{array}$ & $\begin{array}{r}519.80 \pm 102.95 \\
a b \\
74.60 \pm 5.42\end{array}$ & $\begin{array}{r}259.33 \pm 55.55 \\
a \\
5512+6.81\end{array}$ \\
\hline
\end{tabular}

Mean values followed by different superscript letters are significantly different $(\mathrm{p}<0.05)$ 
The result of the lead content in the water showed that they were significantly different among zones. The lead content was lowest in the upstream zone $(0.0037-0.0075 \mathrm{mg} / \mathrm{l})$ and increased in the middle-stream zone $(0.0132-0.0184 \mathrm{mg} / \mathrm{l})$ being highest in the downstream zone $(0.0476-0.0549 \mathrm{mg} / \mathrm{l})$. Furthermore, in the sediment, the lead content was also highest in the middle-stream zone $(2,175.04-31,937.30 \mathrm{mg} / \mathrm{kg})$ and lower in the upstream $(92.76-184.97 \mathrm{mg} / \mathrm{kg})$ and downstream $(504.02-1,514.99 \mathrm{mg} / \mathrm{kg})$ zones. Figure 3 shows the lead contents in the sediment among zones. The contents of cadmium, mercury and zinc were highest in the middle-stream zone, whereas the arsenic content was highest in the downstream zone (Table 3). The iron contents were saturated in all zones.
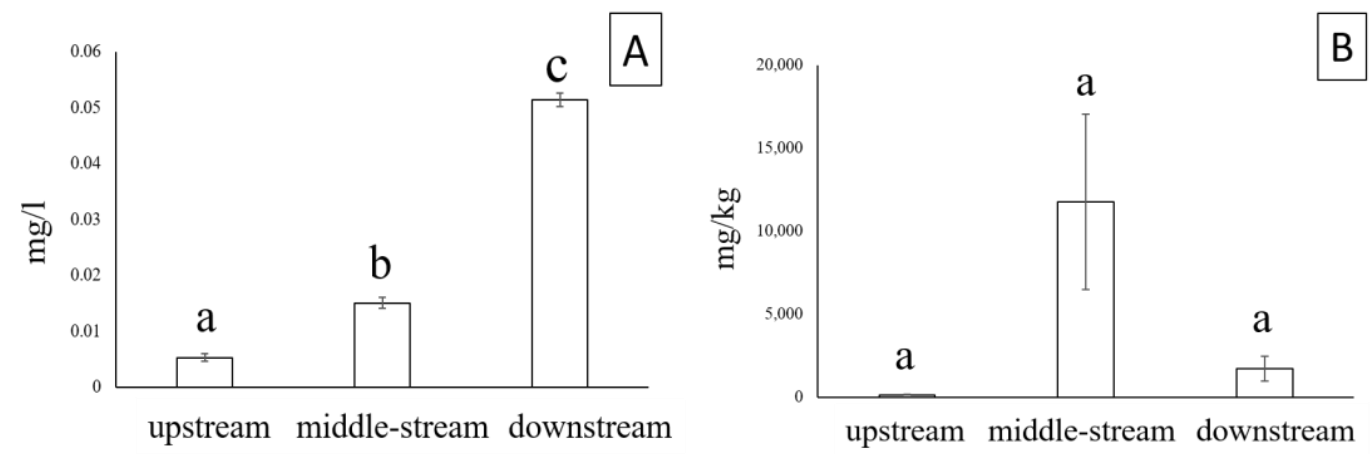

Figure 3. Lead contents with standard error bars in water (A) and sediment (B) of Khli Ti creek

Table 3. Accumulation (mean \pm S.D.) and standard levels $(\mathrm{mg} / \mathrm{kg}$ ) of other heavy metals in sediment of Khli Ti creek $(n=5)$

\begin{tabular}{c|c|c|c|c}
\hline Heavy metal & Upstream zone & Middle-stream zone & Downstream zone & Standard level* $^{*}$ \\
\hline Arsenic (As) & $15.44 \pm 5.16$ & $20.28 \pm 1.82$ & $35.36 \pm 4.06$ & 3.9 \\
Cadmium (Cd) & $0.25 \pm 0.06$ & $0.36 \pm 0.10$ & $0.33 \pm 0.11$ & 37 \\
Zinc (Zn) & $48.59 \pm 5.65$ & $64.77 \pm 11.39$ & $51.182 \pm 24.81$ & - \\
Mercury (Hg) & nd & $0.1 \pm 0.08$ & $0.05 \pm 0.03$ & 23 \\
Iron (Fe) & Saturated & Saturated & Saturated & - \\
\hline
\end{tabular}

*Department of Pollution Control (2004) and nd is non detectable

\section{Lead contents in biotic samples}

We found lead contamination in biotic samples and the degree of contamination in organisms increased in the downstream zone. In contrast, the lowest values foe the lead content in organisms were detected in the upstream zone. The highest lead contents in plankton and plants were found in the downstream zone whereas the lead contents in macroinvertebrates and fish appeared to be high in the middle-stream zone (Table 4).

\section{Bioaccumulation and biomagnification}

Table 5 presents the bioaccumulation and biomagnification results for lead in freshwater organisms. It shows that the highest bioaccumulation values were found in the middle-stream zone. Furthermore, on average, macrophytes had the highest bioaccumulation value followed by macroinvertebrates, plankton and fish, respectively. The biomagnification values increased from the lower trophic to higher trophic levels. In particular, the highest biomagnification value was in the middle-stream zone. 


$$
\text { - } 3903 \text { - }
$$

Table 4. Lead contents (mean \pm S.D., $m g / k g)$ in biotic samples in Khli Ti creek $(n=15)$

\begin{tabular}{|c|c|c|c|c|}
\hline Parameter & Upstream zone & Middle-stream zone & Downstream zone & Standard level* \\
\hline Plankton & $6.93 \pm 0.25^{\mathrm{a}}$ & $7.19 \pm 0.22^{\mathrm{a}}$ & $7.00 \pm 0.14^{\mathrm{a}}$ & - \\
\hline Macroinvertebrates & $370.03 \pm 172.25^{\mathrm{a}}$ & $519.80 \pm 102.95^{a b}$ & $259.33 \pm 55.55^{\mathrm{a}}$ & 0.5 \\
\hline Fish & $76.59 \pm 8.46^{\mathrm{a}}$ & $74.60 \pm 5.42^{a b}$ & $55.12 \pm 6.81{ }^{\mathrm{a}}$ & 0.2 \\
\hline Macrophytes & $4.51 \pm 3.20^{\mathrm{a}}$ & $106.77 \pm 173.32^{\mathrm{a}}$ & $155.89 \pm 211.20^{\mathrm{a}}$ & - \\
\hline
\end{tabular}

Mean values followed by different letters are significantly different $(\mathrm{p}<0.05)$. *Department of Public Health (1986)

Table 5. Bioaccumulation and biomagnification (mean $\pm S . D . \mathrm{mg} / \mathrm{kg}$ ) of lead in freshwater organisms along Khli Ti creek

\begin{tabular}{l|c|c|c}
\hline \multicolumn{1}{c|}{ Factor } & Upstream zone & Middle-stream zone & Downstream zone \\
\hline Bioaccumulation & & & \\
Plankton & $1,112.95 \pm 466.26$ & $1,667.74 \pm 1,452.49$ & $852.11 \pm 245.41$ \\
Macroinvertebrates & $2,923.90 \pm 3,593.24$ & $2,935.33 \pm 2215.91$ & $635.64 \pm 595.77$ \\
Fish & $329.02 \pm 153.35$ & $238.68 \pm 99.08$ & $76.43 \pm 33.56$ \\
Macrophytes & $830.36 \pm 509.34$ & $8,581.21 \pm 10,539.43$ & $3,181.14 \pm 4,487.72$ \\
& & & \\
Biotransference & & & 0.1 \\
Plankton- shrimp & 0.5 & 1.91 & 13.2 \\
Shrimp-dragonfly nymph & - & 1.98 & 0.02 \\
Dragonfly nymph-minnow & 0.28 & 0.02 & 1.9 \\
Minnow-needlefish & 0.31 & 1.78 & \\
\hline
\end{tabular}

\section{Discussion}

Overall, the water quality values met the standards for inland surface water set by the Department of Pollution Control. The water temperature was rather low due to shading from forest cover. Water was also turbid as indicated by the low transparency and high suspended solid contents. This was likely due to erosion from the high discharge during the rainy season. The nitrogen content was relatively high in the upstream zone compared to the other zones, suggesting fertilizer runoff from agricultural areas. In contrast, the phosphorus content was high in the downstream zone. The chlorophyll a content did not reflect nutrient concentrations in the Creek and this could have been the result of the fast flow and suspended solids that inhibited phytoplankton growth. This was similar to the assertion by Mayer and Likens (1987) that algal production had a small portion of energy input in a shaded headwater stream.

The lead content results in the water in the downstream zone exceeded the water quality standard level (0.05 mg/l) of Department of Pollution Control (1992). This was rather consistent with the lead contents in the stream sediment that were relatively lower in the upstream zone and below the standard level for soil quality. However, in the middle-stream and downstream zones, the lead contents in the water were exceptionally higher than the standard levels and increased along with the distance from the inferred source indicating its accumulation. 
Contamination of lead in the water and environment reflects the impact from abandoned old mining at the inferred source (middle-stream) and in the downstream (impacted) area. Our study also revealed that the lead contents in the sediment were very high, similar to previous studies (Department of Pollution Control, 2009). In particular, the highest lead content was detected around the old abandoned mining area in the middle-stream zone, similar to Gomes Ribeiro et al. (2017). The detected level of lead in the middle-stream zone was approximately 25 times higher than the standard level $(400 \mathrm{mg} / \mathrm{kg}$ ) for soil quality set by Department of Pollution Control (2004) for Thailand and much higher than in other studies (Beane et al., 2016; Pavlowsky et al., 2017). The lead content in the sediment of the downstream zone also exceeded the standard level reflecting the fact that contaminated sediment can be carried downstream from the inferred source by stream flow. This is consistent with the results for the lead concentration in the water that was highest in the downstream zone as mentioned earlier. A similar case was reported for metal-polymetallic tin mining of the Potosí deposits in Southern Bolivia which began operation in 1945 and has led to severe contamination of the Pilcomayo River's water and sediments for at least $200 \mathrm{~km}$ downstream of the mines (Miller et al., 2004). The study of Pavlowsky et al. (2017) also showed that the lead concentrations in the channel and floodplain sediments were above the background levels from mine sources for up to $171 \mathrm{~km}$ downstream.

The analyzed sediment data also revealed other heavy metal contents which were high in the middle-stream and downstream zones. In particular, the arsenic and zinc contents were higher than for the other metals and this could have been due to these metal forms usually being associated with mining (Davies, 1987; Ferreira da Silva et al., 2004). Iron contents are usually abundant $(>10 \mathrm{~g} / \mathrm{kg})$ in this area.

This study revealed the accumulation of lead in organisms from producers to consumers that were higher than in previous studies (Table 6). We found the lead content in plankton was relatively lower than in other organisms. However, it should be noted that the lead content from plankton could be a combination of plankton and suspended sediment since some sediment could not be separated through filtration.

Table 6. Lead contamination ranges in the environment and freshwater organisms in Khli Ti creek from previous years

\begin{tabular}{|c|c|c|c|c|c|c|c|}
\hline \multirow{2}{*}{$\begin{array}{c}\text { Lead } \\
\text { content }\end{array}$} & \multicolumn{6}{|c|}{ Year } & \multirow[b]{2}{*}{$2017 *$} \\
\hline & 1998 & 1999 & $2000-2003$ & 2004-2007 & 2008 & 2009 & \\
\hline Water $(\mathrm{mg} / \mathrm{l})$ & $0.005-0.55$ & $0.003-0.08$ & $0.001-0.256$ & $0.005-0.287$ & 0.005-0.06 & $0.007-0.896$ & $0.0037-0.0549$ \\
\hline $\begin{array}{l}\text { Sediment } \\
(\mathrm{mg} / \mathrm{kg})\end{array}$ & $402-65,771$ & $228-68,920$ & $152-118,872$ & $115-143,097$ & $145-105,943$ & $141-117,000$ & $92.76-31,937.30$ \\
\hline Fish $(\mathrm{mg} / \mathrm{kg})$ & $5.8-81.8$ & - & - & $1.65-8.85$ & $0.4-8.48$ & $0.08-16.3$ & $55.12-76.59$ \\
\hline Crab $(\mathrm{mg} / \mathrm{kg})$ & $222.8-451.8$ & - & - & $13.4-52$ & 10.8 & $13.6-82.6$ & $11.16-52.77$ \\
\hline $\begin{array}{l}\text { Shrimp } \\
(\mathrm{mg} / \mathrm{kg})\end{array}$ & 130.17 & - & - & $42.5-164$ & $4.14-22.9$ & $0.11-4.27$ & $1.23-16.16$ \\
\hline $\begin{array}{l}\text { Mollusc } \\
(\mathrm{mg} / \mathrm{kg})\end{array}$ & 125.6 & - & - & $42.3-112$ & 59.8 & $186-471$ & $3.17-91.42$ \\
\hline
\end{tabular}

Source: Department of Pollution Control (2009) and data of 2017 are from this study

Freshwater macrophytes had also a high content of lead due to their assimilation through root uptake (Pourrut et al., 2011) from the contaminated sediment. Among freshwater organisms, macroinvertebrates appeared to be the most affected by lead 
contamination (Beane et al., 2016) because they dwell in the benthic zone and thus have a greater chance of exposure to lead accumulation through feeding and direct contact (Yoo-iam et al., 2014). The highest lead content in macroinvertebrates was detected in the middle-stream zone. In a higher trophic level, fish had a much lower lead content than macroinvertebrates. Therefore, it could be stated that the contents of lead in the sediment were somewhat paralleled by their content in benthic macroinvertebrates as was also observed in water (Kiffney and Clements, 1993). The BAF values in macrophytes were high due to direct uptake through roots since the higher heavy metal concentration in the soil is, the higher will be the concentration in plants (Davies, 1987). In addition, lead accumulating in organisms is of concern, as all organisms had higher lead contents than the recommended standard levels for food set by Department of Public Health (1986) and by the World Health Organisation (WHO) of $1 \mathrm{mg} / \mathrm{kg}$ and $25 \mu \mathrm{g} / \mathrm{g}$ for fish, respectively. Therefore, it would be wise to avoid any consumption of freshwater flora and fauna from the affected area since lead is one the major threats for heavy metal contamination of food chain (Hezbullah et al., 2016).

The results of bioaccumulation identified the bioaccumulation potential of the organisms and the metal concentrations in the water. The BAF values of all organisms were higher than 100 meaning that the organisms had potential to accumulate heavy metals (Yu et al., 2012). Our results showed marked lead accumulation when compared to other studies. For example, in Loei province, Thailand, the BAF values of lead in fish around a gold mining area were in the range 44.30-133.90 mg/kg (Intamat et al., 2016). Table 5 indicates the trophic transfer of lead in the stream food web as lead increased with the trophic level (from producer to primary consumer) in the middle-stream zone around the old mining area because biomagnification of heavy metals occurs when the values of the biotransference factors of heavy metals between prey and predator are greater than one (Gray, 2002; Misztal-Szkudlinska et al., 2011) and when an increase in trace metal concentration occurs through at least two trophic levels in a food chain (Barwick and Maher, 2003). On the contrary, biomagnification in the upstream zone did not occur due to lower concentrations of lead there in the environment and organisms.

\section{Conclusion}

This study highlighted the lead contamination from old mining activity and its effects on the water, sediment and freshwater organisms in Khli Ti creek, Kanchanaburi province, western Thailand. The middle-stream zone around the mine area had highest lead content in the sediment whereas the downstream zone had the highest concentrations of lead in the water. Lead accumulation in plankton, macroinvertebrates, fish and macrophytes was also detected. Furthermore, lead can be passed through the food web as indicated by the biomagnification factor from producers to consumers in the most contaminated zone around the mining area. Based on our results, the lead contents detected in the environment and the food web may pose a potential risk to human health and may also cause acute and chronic impacts on freshwater organisms.

Acknowledgements. This research was funded by the Kasetsart University Research and Development Institute (KURDI) during 2016-2017. We are also grateful to the staff of the Department of Pollution Control for useful information regarding sampling sites and field work planning. Lastly, we thank the Headman of Khli Ti village for background information, site navigation and fieldwork assistance. 


\section{REFERENCES}

[1] AOAC. (2016): Official Methods of Analysis of AOAC International. - (20th ed.) AOAC International Suite, Maryland USA.

[2] APHA. (American Public Health Association) (2005): Standard Methods for the Examination of Water and Wastewater. - (21th ed.) American Public Health Association, Washington, DC, USA.

[3] Barwick, M., Maher, W. (2003): Biotransference and biomagnification of selenium, copper, cadmium, zinc, arsenic and lead in a temperate seagrass ecosystem from Lake Macquarie Estuary, NSW. - Australia Marine Environmental Research 56: 471-502.

[4] Beane, S. J., Comber, S. D. W., Long, P. R. (2016): Abandoned metal mines and their impact on receiving waters: a case study from Southwest England. - Chemosphere 153: 294-306.

[5] Chen, C. Y., Stemberger, R. S., Klaue, B., Blum, J. D., Pickhardt, P. C., Folt, C. L. (2000): Accumulation of heavy metals in food web components across a gradient of lakes. - Limnology and Oceanography 45(7): 1525-1536.

[6] Cui, B., Zhang, Q., Zhang, K., Liu, X., Zhang, H. (2011): Analyzing trophic transfer of heavy metals for food webs in the newly-formed wetlands of the Yellow River Delta, China. - Environmental Pollution 159(5): 1297-1306.

[7] Davies, B. E. (1987): Consequences of environmental contamination by lead mining in Wales. - Hydrobiologia 149(1): 213-220.

[8] Department of Pollution Control. (1992): Water Quality Standard for Surface Waters. http://infofile.pcd.go.th/law/3_14_water.pdf?CFID=2107177\&CFTOKEN=92100960. (in Thai).

[9] Department of Pollution Control. (2004): Soil quality Standard for Living and Agriculture. $\quad-\quad$ Available at http://infofile.pcd.go.th/law/9_1_soil.pdf?CFID=2107177\&CFTOKEN=92100960. （in Thai).

[10] Department of Pollution Control. (2009): Contamination of Lead in Khli Ti Creek and Disseminate Information to the Public. - Available at http://infofile.pcd.go.th/mgt/situation_kity52.pdf?CFID=2107177\&CFTOKEN=9210096 0 . (in Thai).

[11] Department of Public Health. (1986): Contaminated Food Standard. - Available at http://food.fda.moph.go.th/law/data/announ_moph/P98.pdf. (in Thai).

[12] Dudka, S., Adriano, D. C. (1995): Environmental impacts of metal ore mining and processing: a review. - Journal of Environmental Quality 26(3): 590-602.

[13] Ferreira, da S. E., Zhang, C., Pinto, L. S., Patinha, C., Reis, P. (2004): Hazard assessment on arsenic and lead in soils of Castromil gold mining area, Portugal. - Applied Geochemistry 19(6): 887-898.

[14] Gomes Ribeiro, D. R., Faccin, H., Dal Molin, T. R., de Carvalho, L. M., Amado, L. L. (2017): Metal and metalloid distribution in different environmental compartments of the middle Xingu River in the Amazon, Brazil. - Science of the Total Environment 605: 6674.

[15] Goodyear, K. L., McNeill, S. (1999): Bioaccumulation of heavy metals by aquatic macroinvertebrates of different feeding guilds: a review. - Science of the total Environment 229(1-2): 1-19.

[16] Gray, J. S. (2002): Biomagnification in marine systems: the perspective of an ecologist. Marine Pollution Bulletin 45: 46-52.

[17] Greenpeace Thailand. (2012): Statement on Lead Contamination in Khli Ti Creek. Available at http://www.greenpeace.org/seasia/th/news/coalition-statement-on-klitycreek-pollution/. (in Thai). 
[18] Hezbullah, M., Sultana, S., Chakraborty, S. R., Patwary, M. (2016): Heavy metal contamination of food in a developing country like Bangladesh: An emerging threat to food safety. - Journal of Toxicology and Environmental Health Sciences 8(1): 1-5.

[19] Horowitz, J., Elrick, K. A., Cook, R. B. (1993): Effect of mining and related activities on the sediment trace element geochemistry of lake Coeur D'Alene, Idaho, USA. Part I: Surface sediments. - Hydrological Processes 7(4): 403-423.

[20] Intamat, S., Phoonaploy, U., Sriuttha, M., Tengjaroenkul, B., Neeratanaphan, L. (2016): Heavy metal accumulation in aquatic animals around the gold mine area of Loei province, Thailand. - Human Ecological Risk Assessment 22(6): 1418-1432.

[21] Kaushik, A., Kansal, A., Meena, S., Kumari, S., Kaushik, C. P. (2009): Heavy metal contamination of river Yamuna, Haryana, India: assessment by metal enrichment factor of the sediments. - Journal of Hazardous Materials 164(1): 265-270.

[22] Kiffney, P. M, Clements, W. H. (1993): Bioaccumulation of heavy metals by benthic invertebrates at the Arkansas river, Colorado. - Environmental Toxixology and Chemistry 12(8): 1507-1517.

[23] Laskowski, R. (1991): Are the top carnivores endangered by heavy metal biomagnification? - Oikos 60(3): 387-390.

[24] Lee, B., Duong, C. N., Cho, J., Lee, J., Kim, K., Seo, Y., Kim, P., Choi, K., Yoon, J. (2012): Toxicity of citrate-capped silver nanoparticles in common carp (Cyprinus carpio). - Journal of Biomedical Biotechnoly. Doi:10.1155/2012/262670.

[25] Mayer, M. S., Likens, G. E. (1987): The importance of algae in a shaded headwater stream as food for an abundant caddisfly (Trichoptera). - Freshwater Science 6(4): 262269.

[26] Mazej, Z., Sayegh-Petkovšek, S. A., Pokorny, B. (2010): Heavy metal concentrations in food chain of Lake Velenjsko Jezero, Slovenia: an artificial lake from mining. - Archives of Environmental Contamination and Toxicology 58(4): 998-1007.

[27] Miller, P. A., Munkittrick, K. R., Dixon, D. G. (1992): Relationship between concentrations of copper and zinc in water, sediment, benthic invertebrates, and tissues of white sucker (Catostomus commersoni) at metal-contaminated sites. - Canadian Journal of Fisheries and Aquatic Sciences 49(5): 978-984.

[28] Miller, J. R., Hudson-Edwards, K. A., Lechler, P. J., Preston, D., Macklin, M. G. (2004): Heavy metal contamination of water, soil and produce within riverine communities of the Río Pilcomayo basin, Bolivia. - Science of the Total Environment 320(2-3): 189-209.

[29] Misztal-Szkudlinska, M., Szefer, P., Konieczka, P., Namiesnik, J. (2011): Biomagnification of mercury in trophic relation of great cormorant (Phalacrocorax carbo) and fish in the Vistula Lagoon, Poland. - Environmental Monitoring Assessment 176: 439-449.

[30] Moiseenko, T. I., Kudryavtseva, L. P. (2001): Trace metal accumulation and fish pathologies in areas affected by mining and metallurgical enterprises in the Kola Region, Russia. - Environmental Pollution 114(2): 285-297.

[31] Nakayama, S. M. M., Ikenaka, Y., Muzandu, K., Choongo, K., Oroszlany, B., Teraoka, H., Mizuno, N., Ishizuka, M. (2010): Heavy metal accumulation in lake sediments, fish (Oreochromis niloticus and Serranochromis thumbergi), and crayfish (Cherax quadricarinatus) in Lake Itezhi-tezhi and Lake Kariba, Zambia. - Archives of Environmental Contamination and Toxicology 59(2): 291-300.

[32] Newman, M. C., McIntosh, A. W. (eds.). (1991): Metal Ecotoxicology Concepts and Applications. - Lewis Publishing, Inc., Michigan, USA.

[33] Pavlowsky, R. T., Lecce, S. A., Owen, M. R., Martin, D. J. (2017): Legacy sediment, lead, and zinc storage in channel and floodplain deposits of the Big River, old lead belt mining district, Missouri, USA. - Geomorphology 299: 54-75.

[34] Pourrut, B., Shahid, M., Dumat, C., Winterton, P., Pinelli, E. (2011): Lead uptake, toxicity, and detoxification in plants. - Reviews of Environmental Contamination and Toxicology 213: 113-36. 
[35] Thorslund, J., Jarsjö, J., Chalov, S. R., Belozerova, E. V. (2012): Gold mining impact on riverine heavy metal transport in a sparsely monitored region: the upper Lake Baikal Basin case. - Journal of Environmental Monitoring 14: 2780-2792.

[36] Tupwongse, V., Parkpian, P., Watcharasit, P., Satayavivad, J. (2007): Determination of level of Mn, As and other metals in water, sediment, and biota from Phayao Lake, Northern Thailand and assessment of dietary exposure. - Journal of Environmental Science and Health Part (A) 42: 1029-1041.

[37] US Environmental Protection Agency (USEPA). (2001): Water Quality Criterion for the Protection of Human Health: Methylmercury. - EPA-823-R-01-001, Final. Washington, DC, USA.

[38] Varol, M. (2011): Assessment of heavy metal contamination in sediments of the Tigris River (Turkey) using pollution indices and multivariate statistical techniques. - Journal of Hazardous Materials 195(15): 355-364.

[39] Walkley, A., Black, I. A. (1934): An examination of Degtjareff method for determining soil organic matter and a proposed modification of the chromic acid titration method. Soil Science 37: 29-37.

[40] Yoo-iam, M., Chaichana, R., Satapanajaru, T. (2014): Toxicity, bioaccumulation and biomagnification of silver nanoparticles on green algae (Chlorella sp.), water flea (Moina macrocopa), silver barb (Barbonymus gonionotus) and blood worm (Chironomus spp.).Chemical Speciation and Bioavailability 26(4): 257-265.

[41] Yu, T., Zhang, Y., Hu, X. (2012): Distribution and bioaccumulation of heavy metals in aquatic organisms of different trophic levels and potential health risk assessment from Taihu lake, China. - Ecotoxicology Environmental Safety 81: 55-64. 